\title{
Beyond Classical Inheritance: The Influence of Maternal Genotype upon Child's Brain Morphology and Behavior
}

\author{
Noortje J.F. van der Knaap, ${ }^{1}$ Hanan El Marroun, ${ }^{2,3}$ Floris Klumpers, ${ }^{1}$ Sabine E. Mous, ${ }^{2,3}$ Vincent W.V. Jaddoe, $, 3,4,6$ \\ Albert Hofman, ${ }^{3,4}$ Judith R. Homberg, ${ }^{1}$ Tonya White, ${ }^{2,5}$ Henning Tiemeier, ${ }^{2,3,4}$ and Guillén Fernández ${ }^{1}$ \\ ${ }^{1}$ Donders Institute for Brain, Cognition, and Behaviour, Department of Cognitive Neuroscience, Radboud University Medical Center, 6500 HB Nijmegen, \\ The Netherlands, and ${ }^{2}$ Department of Child and Adolescent Psychiatry, ${ }^{3}$ Generation R Study Group, ${ }^{4}$ Department of Epidemiology, ${ }^{5}$ Department of \\ Radiology, and ${ }^{6}$ Department of Pediatrics, Erasmus Medical Centre, 3000 CB Rotterdam, The Netherlands
}

Genetic variance has been associated with variations in brain morphology, cognition, behavior, and disease risk. One well studied example of how common genetic variance is associated with brain morphology is the serotonin transporter gene polymorphism within the promoter region (5-HTTLPR). Because serotonin is a key neurotrophic factor during brain development, genetically determined variations in serotonin activity during maturation, in particular during early prenatal development, may underlie the observed association. However, the intrauterine microenvironment is not only determined by the child's, but also the mother's genotype. Therefore, we hypothesized that maternal 5-HTTLPR genotype influences the child's brain development beyond direct inheritance. To test this hypothesis, we investigated 76 children who were all heterozygous for the 5-HTTLPR ( $\mathrm{sl}$ ) and who had mothers who were either homozygous for the long (ll) or the short allele (ss). Using MRI, we assessed brain morphology as a function of maternal genotype. Gray matter density of the somatosensory cortex was found to be greater in children of ss mothers compared with children of ll mothers. Behavioral assessment showed that fine motor task performance was altered in children of 11 mothers and the degree of this behavioral effect correlated with somatosensory cortex density across individuals. Our findings provide initial evidence that maternal genotype can affect the child's phenotype beyond effects of classical inheritance. Our observation appears to be explained by intrauterine environmental differences or by differences in maternal behavior.

Key words: child; development; gray matter density; maternal genotype; serotonin transporter polymorphism; somatosensory cortex

\section{Introduction}

It is well established that genetic variance is associated with variance in brain morphology (Eyler et al., 2011; Chen et al., 2012). Such genetic variation, in combination with environmental factors, contributes to differences in cognition and behavior and to differences in vulnerability for mental disorders (Caspi et al., 2003). However, it has been hypothesized that not only does the individuals' genome influence brain development, but the maternal genome does as well (Halmøy et al., 2010). This does not refer

\footnotetext{
Received Feb. 5, 2014; revised May 30, 2014; accepted June 4, 2014.

Author contributions: N.J.F.v.d.K., F.K., V.W.V.J., A.H., J.R.H., T.W., H.T., and G.F. designed research; N.J.F.v.d.K., H.E.M., S.E.M., and T.W. performed research; N.J.F.v.d.K. and F.K. analyzed data; N.J.F.v.d.K., H.E.M., F.K., S.E.M., V.W.V.J., A.H., J.R.H., T.W., H.T., and G.F. wrote the paper.

The Generation R Study is conducted by the Erasmus Medical Centre in close collaboration with the School of Law and Faculty of Social Sciences of the Erasmus University Rotterdam, the Municipal Health Service Rotterdam area, the Rotterdam Homecare Foundation, and the Stichting Trombosedienst and Artsenlaboratorium Rijnmond (STAR), Rotterdam, The Netherlands. The general design of Generation R Study is made possible by financial support from the Erasmus Medical Center, Rotterdam, the Erasmus University Rotterdam, the Netherlands Organization for Health Research and Development (ZonMw), the Netherlands Organisation for Scientific Research (NW0), the Ministry of Health, Welfare and Sport, and the Ministry of Youth and Families. In addition, the Sophia Children's Hospital Fund (Grant SSW0-616) and NWO Brain and Cognition (Grant 433-09-311) supported this work financially. We thank the general practitioners, hospitals, midwives, and pharmacies in Rotterdam for their contributions to this study.

The authors declare no competing financial interests.

Correspondence should be addressed to Noortje J.F. van der Knaap, RUMC, Route 126, Department of Cognitive Neuroscience, P.0. Box 91016500 HB Nijmegen, The Netherlands. E-mail: N.vanderknaap@donders.ru.nl.

DOI:10.1523/JNEUROSCI.0505-14.2014

Copyright $\odot 2014$ the authors $\quad 0270-6474 / 14 / 349516-06 \$ 15.00 / 0$
}

to classical inheritance, but rather to additional effects of maternal genotype on the child's brain. Maternal genotype may influence the intrauterine microenvironment (James et al., 2010; Pilsner and $\mathrm{Hu}, 2010$ ) or it may affect maternal behavior, possibly altering the child's environment (Bakermans-Kranenburg and van IJzendoorn, 2008). Exposure to such environmental differences during vulnerable developmental stages may cause longlasting and critical changes to the child's brain. Therefore, we investigated whether maternal genotype affects a child's brain and behavior while controlling for the child's own genetic makeup.

To test this maternal genotype hypothesis, we selected a well known and common polymorphic variant within the serotonin system, the serotonin-transporter-linked polymorphic region (5HTTLPR). Short (s) and long (l) variants of that region exist, depending on a deletion or insertion of a repetitive 44 bp sequence in the promotor region (Heils et al., 1996). The short variant is associated with altered transcriptional properties leading to reduced serotonin transporter availability, which in turn is associated with cognitive and behavioral impairments and increased vulnerability for stress-related mental disorders (Caspi et al., 2010). We selected this polymorphism because serotonin acts as a neurotrophic factor directly influencing brain development (Gaspar et al., 2003). Further, mouse embryonic development is altered if the mother does not produce serotonin (Côté et al., 2007). Therefore, small differences in the serotonin system may affect the intrauterine 
microenvironment caused by different maternal genotypes, affecting the child's neurodevelopment. Additionally or alternatively, variance in 5-HTTLPR is thought to be associated with variance in emotion and behavior, so maternal genotype may affect the child's environment through maternal behavior prenatally and postnatally (Lesch et al., 1996; Bakermans-Kranenburg and van IJzendoorn, 2008; Homberg and Lesch, 2011). Moreover, recent populationbased studies have shown the effect of serotonin alterations on the developing brain: when a mother takes antidepressants affecting the serotonin system during pregnancy, the fetus' head growth is delayed and the children show more autistic behavior than children of depressed mothers who did not take antidepressants (El Marroun et al., 2012, 2014).

To investigate the hypothesis that maternal genotype affects child brain development beyond classical inheritance, we selected children heterozygous for the 5-HTTLPR polymorphism from the Generation R Study, a prospective population-based study from fetal life onward (White et al., 2013). By comparing heterozygous children of mothers who were homozygous for 5-HTTLPR (ss or 11), we studied whether brain morphology and behavioral performance were influenced by maternal genotype. This proof-of-concept study probes the effect of maternal genotype on neurodevelopment, which may represent an additional mechanism of how maternal genes influence our lives.

\section{Materials and Methods}

Participants. Participants were part of the Generation R Study, a longitudinal population-based study performed in Rotterdam, The Netherlands, which started in 2002. The study included 9778 mothers whom have been extensively monitored and participated in a series of studies together with their child. Blood from mothers and children was sampled for genetic studies (Tiemeier et al., 2012). In September 2009, the Generation R Study started an imaging project investigating prenatal factors on brain development with MRI in children aged 6-8 years (White et al., 2013). For the present study, we selected children of both sexes from that imaging project who were successfully scanned and who had genetic information available for both mother and child ( 458 children). In the analysis, we included children who were heterozygous (sl) for the 5-HTLLPR polymorphism. The second criterion was that the mothers of these children were homozygous for the 5-HTTLPR, carrying either the 11 ( 45 children) or the ss ( 36 children) genotype. The two groups of children will be referred to as maternal 11 or maternal ss group. The study was approved by the Medical Ethical Committee of the Erasmus Medical Centre and informed consent was obtained from a parent or a legal guardian before participation in the study.

Covariates and confounders. To control for possible differences between the groups unrelated to the question at issue, we gathered additional data from both mothers and children that could potentially influence brain development or otherwise confound the associations with maternal genotype. Data were collected in the course of the Generation R Study (for an overview of all questionnaires collected, please see Jaddoe et al., 2010). We obtained information from mothers on prenatal alcohol consumption (1l, $n=39$; ss, $n=31$ ) and smoking (ll, $n=41$; ss, $n=32$ ) during the first, second, and third trimester of pregnancy. Mothers were asked via questionnaires to state whether they never used tobacco or alcohol during pregnancy, until pregnancy was known, or throughout pregnancy (Roza et al., 2007). Additional questionnaires (1l, $n=28$; ss, $n=16$ ) about maternal emotional state [Brief Symptoms Inventory (BSI; Derogatis and Melisaratos, 1983)] and parental disciplining (Child Behavior Conflicts Scale; Straus et al., 1998; Dutch equivalent IJzendoorn and Bakermans-Kranenburg, 2004) were obtained 36 months postnatally. The BSI questionnaire is a validated self-report questionnaire with 53 items of which the symptom subscales for depression and anxiety were assessed (de Beurs, 2004). The Parental Disciplining Questionnaire contains questions on the type and frequency of parental disciplining measures from classical disciplining to physical and psychological harsh parenting styles. Child data on age at scanning, sex, ethnicity and length of gestational period were collected. Ethnicity was classified in groups of "Dutch," "non-Dutch," or "non-Dutch and nonWestern," as described previously (El Marroun et al., 2012).

MRI data acquisition. Before the actual MRI investigation, children were familiarized with the imaging procedure by having an interactive session in a mock scanner. Scanning was performed on a Discovery MR750 3 tesla whole-body MRI system (General Electric) using an 8-channel head coil. The high-resolution structural scan was acquired using a whole-brain $\mathrm{T}_{1}$ inversion recovery fast spoiled gradient recalled (IF-FSPGR) sequence with the following parameters: TR $=10.3 \mathrm{~ms}$, $\mathrm{TE}=4,2 \mathrm{~ms}$, flip angle $=16^{\circ}$, matrix size $=256 \times 256,186$ contiguous sagittal slices with an isotropic voxel size of $0.9 \mathrm{~mm}^{3}$.

MRI data analysis. All images were inspected visually for excessive movement, which could lead to inadequate registration, or other artifacts, which excluded two datasets (one 11 and one ss). Scans of 44 participants in the maternal $\mathrm{ll}$ group and 35 participants in the maternal ss groups were used for analysis. A voxel-based morphometry (VBM) procedure was executed as implemented in SPM8 including the DARTEL registration (http://www.fil.ion.ucl.ac.uk/spm/doc/manual.pdf). To avoid potentially incorrect a priori influences during segmentation due to the adult tissue probability map, the template-o-matic (TOM8) toolbox (Wilke et al., 2003) was used to generate a custom tissue probability map for the average age of the present study ( 7 years). Data were normalized to MNI space both in a modulated and nonmodulated fashion and resampled to $1.5 \mathrm{~mm}$ isotropic voxel size. With the modulated approach, we included the spatial extent of normalization within voxel values, enabling us to compare volumetric differences. The nonmodulated approach leaves this step out, providing us with information on gray matter (GM) density (Ashburner and Friston, 2000, 2001). Subsequently, the images were smoothed using an $8 \mathrm{~mm}$ FWHM kernel, checked for sample homogeneity using the VBM8 toolbox, and outlier images were excluded (three subjects, all in the ss group). Final group sizes used for statistical analysis were 44 children in the maternal 11 group and 32 in the maternal ss group.

The total GM and white matter (WM) volume in native space images were entered as covariates of no interest. We compared the probability estimates of GM and WM between groups by performing a whole-brain voxelwise independent sample $t$ test. Results were statistically thresholded at 0.05 (corrected for FWE multiple comparisons). For further analysis, mean GM probability estimates were extracted from Brodmann areas 1, 2, and 3 on the left hemisphere using Marsbar (Brett et al., 2002). These extracted mean values were correlated with the number of pencil lifts of right-handed children.

Neuropsychological assessment. To assess neuropsychological functioning of the children, the Developmental Neuropsychological Assessment test battery (NEPSY-II) preceded the imaging session (Brooks et al., 2010; Korkman et al., 2013). Within this assessment, five domains were tested, leading to a total of 21 measures within the following five domains: (1) attention and executive functioning, (2) sensorimotor, (3) memory and learning, (4) language, and (5) visual-spatial processing (for full description of tasks, see White et al., 2013). The whole procedure took $\sim 1 \mathrm{~h}$ and was executed in 1 of 4 randomly selected counterbalanced orders. From the participants in the VBM analysis, complete datasets were available of 42 children from the maternal 11 group and 32 children from the maternal ss group.

Statistical analysis. Statistical analysis of the extracted brain volumes were conducted with an independent $t$ test. Analyses of the data from the questionnaires were performed on the sum scores of the measures obtained. Group scores were tested with independent $t$ tests or $\chi^{2}$ tests to compare characteristics between the two groups of children and mothers. In case of significant violation of the normality assumption, a nonparametric Mann-Whitney $U$ test was used. With regard to the neuropsychological assessment, all sum scores were analyzed by means of a Mann-Whitney $U$ test corrected for multiple testing (21 measures) by means of a Bonferroni correction $(p<0.0024)$. Correlation analysis between brain GM density and number of pencil lifts within the visuomotor precision task were performed using a Spearman's rho analysis. All analyses were performed using IBM SPSS statistics software version 19.0. 
Table 1. Descriptive statistics of the participants

\begin{tabular}{|c|c|c|c|}
\hline & $\|$ & SS & Statistics \\
\hline \multicolumn{4}{|l|}{ Child characteristics } \\
\hline $\begin{array}{l}\text { Age at MRI in months } \\
{[\text { mean (SD)] }}\end{array}$ & $90.4(10.9)$ & $92.1(12.1)$ & $\mathrm{t}_{(74)}=-0.644, p=0.52$ \\
\hline Sex (\% boys) & $53.3 \%$ & $60.6 \%$ & $\chi_{(1)}^{2}=0.789, p=0.37$ \\
\hline Ethnicity (\%) & & & $\chi_{(2)}^{2}=1.504, p=0.47$ \\
\hline Dutch & $72.7 \%$ & $59.5 \%$ & \\
\hline Non-Dutch Western & $4.5 \%$ & $6.2 \%$ & \\
\hline Non-Dutch non-Western & $22.8 \%$ & $34.3 \%$ & \\
\hline $\begin{array}{l}\text { Gestational age in weeks } \\
{[\text { mean (SD) }]}\end{array}$ & $40.1(2)$ & $40.0(1)$ & $\mathrm{t}_{(74)}=0.286, p=0.79$ \\
\hline \multicolumn{4}{|l|}{ Maternal characteristics } \\
\hline $\begin{array}{l}\text { Smoking during } \\
\text { pregnancy (\%) }\end{array}$ & & & $\chi_{(2)}^{2}=1.86, p=0.39$ \\
\hline $\begin{array}{l}\text { Never smoked during } \\
\text { pregnancy }\end{array}$ & $78 \%$ & $51.6 \%$ & \\
\hline $\begin{array}{l}\text { Smoked until pregnancy } \\
\text { was known }\end{array}$ & $4.9 \%$ & $22.6 \%$ & \\
\hline $\begin{array}{l}\text { Smoked throughout } \\
\text { pregnancy }\end{array}$ & $17.1 \%$ & $21.8 \%$ & \\
\hline $\begin{array}{l}\text { Alcohol consumption } \\
\quad \text { during pregnancy (\%) }\end{array}$ & & & $\chi_{(2)}^{2}=2.23, p=0.33$ \\
\hline $\begin{array}{l}\text { Never drank during } \\
\text { pregnancy }\end{array}$ & $46.2 \%$ & $51.6 \%$ & \\
\hline $\begin{array}{l}\text { Drank until pregnancy } \\
\text { was known }\end{array}$ & $12.8 \%$ & $22.6 \%$ & \\
\hline $\begin{array}{l}\text { Drank throughout } \\
\text { pregnancy }\end{array}$ & $41.0 \%$ & $25.8 \%$ & \\
\hline \multicolumn{4}{|l|}{$\begin{array}{l}\text { Psychopathology scores } \\
{[\text { mean (SD) }]^{a}}\end{array}$} \\
\hline Anxiety & $0.21(0.4)$ & $0.24(0.3)$ & $\mathrm{U}=485.0, p=0.89$ \\
\hline Depression & $0.17(0.3)$ & $0.22(0.4)$ & $U=536.5, p=0.41$ \\
\hline $\begin{array}{l}\text { Disciplining behavior } \\
{\left[{ }_{\text {mean }}(\mathrm{SD})\right]^{a}}\end{array}$ & $20.8(6.6)$ & $24.4(4.5)$ & $U=305.5, p=0.04$ \\
\hline
\end{tabular}

${ }^{a}$ Assessed at 3 years of child's age.

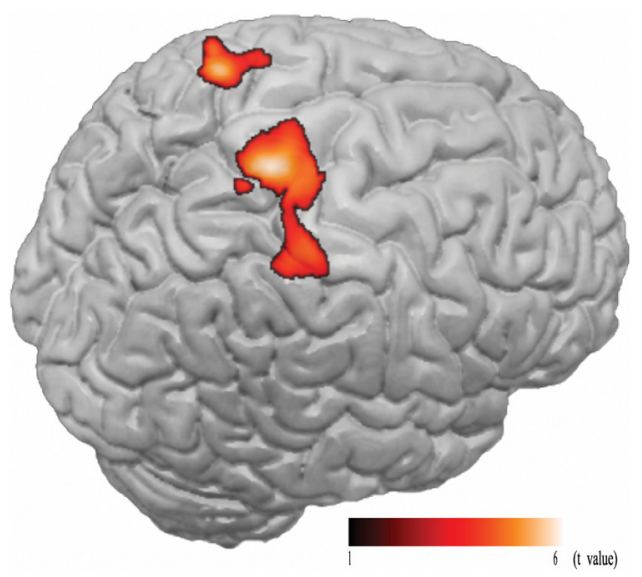

Figure 1. Significantly denser GM in the somatosensory cortex in children with ss mothers compared with children in the maternal II group. Shown is a 3D rendering with color-coded differences in GM density thresholded at $\mathrm{pFWE} \mathrm{E}_{\text {corr }}<0.05$.

\section{Results}

There were no significant differences between groups in several relevant characteristics, including child age at scanning, ethnicity, sex, or gestational age (Table 1). There were also no group differences on the maternal characteristics of smoking or alcohol intake during pregnancy or in maternal emotional state at the child's age of 3 years (Table 1). However, there was a difference in parental disciplining scores. Mothers in the ss group corrected
Table 2. Overview subtests neuropsychological assessment

\begin{tabular}{|c|c|c|c|}
\hline & $\|$ & SS & Statistics \\
\hline \multicolumn{4}{|l|}{ Domain: attention and } \\
\hline \multicolumn{4}{|l|}{ executive functioning } \\
\hline \multicolumn{4}{|l|}{$\begin{array}{l}\text { Auditory attention and } \\
\text { response set }\end{array}$} \\
\hline $\begin{array}{l}\text { Commission mistakes auditory } \\
\text { attention }\end{array}$ & $1.2(4.9)$ & $2.5(7.7)$ & $\mathrm{U}=589.5, p=0.51$ \\
\hline $\begin{array}{l}\text { Omission mistakes auditory } \\
\text { attention }\end{array}$ & $2.6(5.0)$ & $2.8(4.7)$ & $U=670.0, p=0.14$ \\
\hline $\begin{array}{l}\text { Inhibition mistakes auditory } \\
\text { attention }\end{array}$ & $0.5(2.8)$ & $1.5(5.9)$ & $\mathrm{U}=641.0, p=0.64$ \\
\hline $\begin{array}{l}\text { Commission mistakes response } \\
\text { set }\end{array}$ & $3.6(2.3)$ & $3.1(2.5)$ & $\mathrm{U}=481.0, p=0.45$ \\
\hline Omission mistakes response set & $5.9(3.8)$ & $7.6(5.7)$ & $U=610.0, p=0.37$ \\
\hline Inhibition mistakes response set & $1.6(1.6)$ & $1.5(1.8)$ & $U=496.0, p=0.56$ \\
\hline \multicolumn{4}{|l|}{ Statue } \\
\hline Movement of body during statue & $0.7(1.2)$ & $0.5(1.1)$ & $U=610.5, p=0.41$ \\
\hline Eye's open during statue & $0.5(0.7)$ & $0.8(1.2)$ & $\mathrm{U}=754.0, p=0.30$ \\
\hline Producing sound during statue & $0.3(0.6)$ & $0.4(1.1)$ & $\mathrm{U}=661.5, p=0.87$ \\
\hline \multicolumn{4}{|l|}{ Domain: sensorimotor } \\
\hline \multicolumn{4}{|l|}{ Visuomotor precision } \\
\hline Time to complete (s) & $118.3(40)$ & $111(50)$ & $\mathrm{U}=543.5, p=0.17$ \\
\hline Number of border crossings & $19.0(20)$ & $24(22)$ & $U=773.0, p=0.27$ \\
\hline Number of pencil lifts & $6.8(7.2)$ & $3.2(5.4)$ & $\mathrm{U}=318.5, p=0.0013$ \\
\hline \multicolumn{4}{|l|}{ Domain: memory and learning } \\
\hline Memory for faces & $10.4(2.1)$ & $10.8(2.5)$ & $U=763.5, p=0.31$ \\
\hline Memory for faces delayed & $11.0(2.0)$ & $10.7(3.2)$ & $\mathrm{U}=695.5, p=0.80$ \\
\hline \multicolumn{4}{|l|}{ Narrative memory } \\
\hline Free recall of story & $15.5(7.3)$ & $14.2(7.5)$ & $\mathrm{U}=593.5, p=0.63$ \\
\hline Recognition of story & $13.9(1.6)$ & $13.8(1.5)$ & $\mathrm{U}=603.5, p=0.71$ \\
\hline \multicolumn{4}{|l|}{ Domain: language } \\
\hline \multicolumn{4}{|l|}{ Word generation } \\
\hline Number of animals & $13.9(4.1)$ & $13.5(4.6)$ & $\mathrm{U}=478.5, p=0.90$ \\
\hline Number of food and drink items & $13.5(4.4)$ & $11.3(4.5)$ & $\mathrm{U}=352.0, p=0.06$ \\
\hline \multicolumn{4}{|l|}{ Domain: visuospatial processing } \\
\hline Arrows & $25.4(4.1)$ & $24.1(6.9)$ & $U=559.0, p=0.94$ \\
\hline Route finding & $6.9(2.9)$ & $6.7(2.7)$ & $U=510.5, p=0.65$ \\
\hline Geometric puzzles & $27.7(4.0)$ & $26.1(5.5)$ & $U=527.0, p=0.17$ \\
\hline
\end{tabular}

All measures depicted are mean (SD) or sum scores of the measures. Values are considered significant if $p<0.0024$ (Bonferroni corrected for multiple testing).

their children more often or more intensely than mothers in the ll group (U 305.5, $p=0.04$; Table 1).

Whole-brain analysis of GM and WM revealed no significant differences between maternal genotype groups when analyzing modulated, normalized values (FWE whole-brain corrected $>$ $0.05)$. However, groups differed in nonmodulated, normalized GM values. This difference in GM density was found bilaterally in the postcentral somatosensory cortex. Children in the maternal ss group had higher GM density in the somatosensory cortex compared with offspring of mothers with two copies of the 1 allele. Similar patterns were observed in both the left $\left(t_{(73)}=5.83, p=\right.$ 0.007 , FWE whole-brain corrected; cluster size 1398 voxels) and the right hemisphere $\left(t_{(73)}=5.47, p=0.02\right.$, FWE whole-brain corrected; cluster size 455 voxels; Fig. 1). When including parental disciplining scores as a covariate into the analysis, density in the somatosensory cortex remained significantly different between groups. Identical analyses of WM did not reveal any significant group differences (FWE whole-brain corrected $>0.05$ ).

The neuropsychological assessment revealed one test in which groups differed significantly after correcting for multiple comparisons (Table 2). This finding was obtained for the sensorimotor domain, which was assessed with a visuomotor precision task in which the children were instructed to draw lines inside two 
curved tracks as quickly and accurate as possible. The performance differed between the maternal ss and 11 groups $(\mathrm{U}=$ $318.50, p=0.0013$ ) when considering the number of times the child lifted the pencil of the paper before continuing drawing [maternal ll group: mean $(\mathrm{SD})=6.8(7.2)$, maternal ss group: mean $(\mathrm{SD})=3.2(5.4)$; Fig. 2 ]

Finally, given the location of the GM differences in the somatosensory cortex and the behavioral results within the sensorimotor domain, we investigated the potential association between both findings. Given the likely effect of handedness, we tested for a correlation in the subsample of right-handed children with the contralateral left hemisphere somatosensory cortex cluster. A nonparametric Spearman's rho correlation was conducted on the number of pencil lifts in right-handed children $(n=68)$ and left primary somatosensory cortex, as defined by Brodmann areas 1,2 , and 3 . This analysis revealed a negative correlation $\left[r_{s}\right.$ (66) $-0.258 p=0.034$; Fig. 3]. In other words, children with denser GM in the left somatosensory cortex lift their pencil less often in a visuomotor precision task. To control for potential effects of maternal genotype on this correlation, we reanalyzed the data within each maternal genotype group separately. Although this analysis confirmed the negative correlation with an even smaller $p$-value in the ss group $\left(r_{s}(29)-0.393, p=0.029\right)$, it failed to reveal a significant correlation in the 11 group $\left(r_{s}(35)=\right.$ $0.170, p=0.314)$. This result suggests a functional association between somatosensory cortex morphology and sensorimotor ability.

\section{Discussion}

In the present study, we investigated whether maternal genotype has an effect on the child's brain development beyond classical inheritance. We hypothesized that variance in the maternal genotype, independent of the child's own genotype, is associated with variance in the child's brain morphology and behavioral performance. Initial evidence suggests that maternal genotype modulates disease risk of the offspring (Halmøy et al., 2010; James et al., 2010). Consistent with this idea, we found that common variance of the serotonin transporter gene in the maternal genome is associated with variance in brain morphology and related behavioral performance in the offspring. More specifically, we revealed that genomic variance in the serotonin transporter of the mother is associated with offspring's morphology of the somatosensory cortex and associated behavioral performance in a visuomotor precision task.

When considering influences of maternal genotype upon the child's development beyond classical heritability, two potential mechanisms could underlie the observed variance in the child. The first potential mechanism consists of differences in the intrauterine microenvironment during prenatal development (James et al., 2010; Pilsner and $\mathrm{Hu}, 2010$ ). A second mechanism involves influences by genotype-related alterations of maternal behavior (Lahey et al., 2012). These two mechanisms are not mutually exclusive because they could occur in parallel or interact with each other.

The placenta, the uterine lifeline between mother and child, provides an efficient exchange of nutrition and oxygen. It also allows the inevitable exposure to maternal factors, some of which could influence brain development. A well studied example for such an effect is folic acid, the supplementation of which by the mother decreases the risk for neural tube defects in the child (Wallingford et al., 2013). Therefore, biological variance within the intrauterine microenvironment is a plausible mechanism, especially early during pregnancy, when the embryo's development

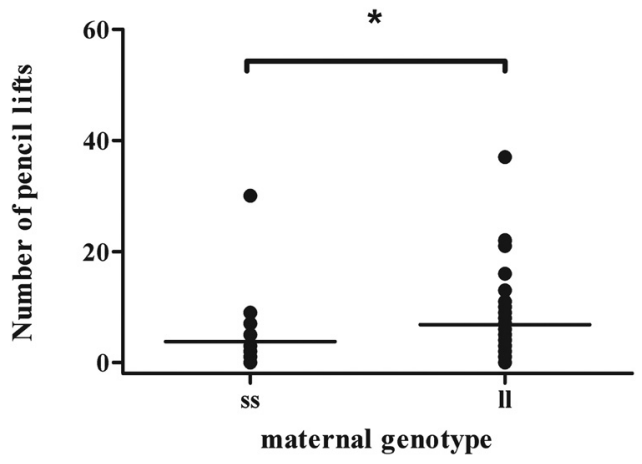

Figure 2. Children of ss mothers lift their pencils significantly less often than children in the maternal II group $(U=318.5, p=0.0013)$. Individual values (dots) and group means (horizontal line) are depicted.

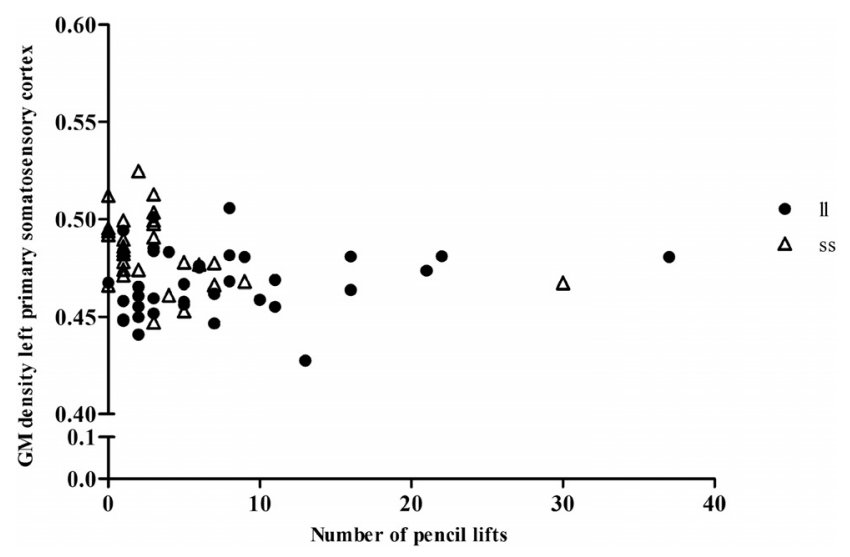

Figure 3. Scatter plot of GM density in the left primary somatosensory cortex (Brodmann areas 1, 2 , and 3) and number of pencil lifts in the visuomotor precision task in right-handed children (nonparametric Spearman's rho correlation: $\left.r_{s}(66)-0.258, p=0.034\right)$.

is particularly sensitive (Carlson, 2008) and is dependent on maternal contributions to the intrauterine microenvironment (John and Hemberger, 2012).

Serotonin, like folic acid, plays a critical role during brain development, when it acts as a neurotrophic factor modulating several processes of neuronal organization (Gaspar et al., 2003). During the gestational period in mice, which typically lasts $28 \mathrm{~d}$, the embryonic part of the placenta starts producing its own serotonin from gestational day 10 onward, presumably for the purpose of regulating and sustaining serotonin production for brain development independently of the mother (Bonnin et al., 2011). This suggests that the embryo may be dependent on serotonin provided by the mother before this period. The possible dependency of the offspring on maternal serotonin has been shown in a study in which mice embryos that were genetically fully capable of producing serotonin, but were conceived by a mother mouse that was unable to produce serotonin, suffered from maldevelopment. Compared with control mice from mothers with intact serotonin production, these fetuses had less proliferation of neopallial cortex and abnormally shaped morphology in the rhombencephalic regions and the roof of the neopallial cortex, a precursor of the cortex (Côté et al., 2007). This shows that differences in maternal genotype within the serotonin system can influence embryonic and/or fetal brain development via an effect on the intrauterine microenvironment. This effect could be exerted directly via differences in serotonin levels reaching the embryo or fetus. Alternatively, differences in the maternal serotonin system may change other maternal meta- 
bolic, endocrine, or autonomic characteristics, which in turn act upon embryonic or fetal development.

Other studies on prenatal influences of serotonin in humans have focused on commonly used antidepressants: selective serotonin reuptake inhibitors (SSRIs). SSRIs taken during pregnancy can pass the placental barrier and reach the embryo or fetus and have shown to affect brain development (Hendrick et al., 2003). In rodents, SSRI exposure during pregnancy led to altered behavioral measures in the offspring and an altered morphology in the somatosensory cortex; for example, shorter dendritic length in the layer IV spiny stellate cells (Lee, 2009; Olivier et al., 2011; Rodriguez-Porcel et al., 2011; Miceli et al., 2013). It is tempting to speculate that such differences in cortical organization have led directly or indirectly to the differences in GM density observed here. In addition, it was shown within the present cohort that children of mothers who take SSRIs during pregnancy tend to have smaller head sizes and more autistic behavioral traits than children of depressed mothers who did not take SSRIs (El Marroun et al., 2012; El Marroun et al., 2014). Moreover, behavioral studies have indicated that SSRI exposure during pregnancy is related to a delayed attainment of certain developmental milestones in infancy in several domains, including motor function and language (Pedersen et al., 2010; Weikum et al., 2012; De Vries et al., 2013). Therefore, there is cumulative evidence that serotonergic differences within the intrauterine microenvironment can alter brain development. These alterations may be more pronounced in the somatosensory cortex, as supported by our findings.

Differences in maternal behavior offer another mechanism by which the maternal genotype may be linked to neurodevelopmental alterations in the child. We found genotype-dependent differences in parental disciplining. Moreover, 5-HTTLPR variation has been shown previously to be associated with behavioral traits (Lesch et al., 1996) and parenting behavior (BakermansKranenburg and van IJzendoorn, 2008). These factors may influence the environment in which the child grows up. For example, anxious mothers grant their children less autonomy (NicolHarper et al., 2007), which could lead to a situation in which the child is systematically exposed to either different or fewer activities, which in turn may alter brain morphology (Maguire et al., 2000; Herholz and Zatorre, 2012). However, we aimed to control for behavioral differences between the maternal groups with the goal if compensating for these differences (BakermansKranenburg and van IJzendoorn, 2008). Correcting for differences in parental disciplining did not account for the differences found in brain morphology. Nevertheless, other differences in maternal behavior that were not controlled for in this cohort study may have created different environments for the child, which in turn may have led to differences in brain morphology and visuomotor skills.

This study was set up as a proof-of-concept study by which we aimed at providing initial evidence for the influence of maternal genotype on child development. We had the opportunity to use data from a large prospective prenatal cohort instead of a preselected child population. This offered the benefit of extensive information on many child and maternal characteristics. This reduced the chance of selection bias and enabled us to control for several important factors throughout life in a prospective fashion. Apart from these strengths of the study, there also are several limitations. To our knowledge, this is the first human study investigating the consequences of maternal serotonin transporter polymorphism upon the offspring's phenotype. Although we have provided a conceptual replication within our study by revealing an effect on brain morphology and one on behavioral performance, additional studies are necessary to confirm this proof-of-concept, and thus the maternal genotype hypothesis, further. In addition, the investigation of one specific polymorphism limits our insight into the full scale of potential consequences of maternal genotype. Other genetic differences between mothers or children that are independent of serotonin transporter polymorphism could not be investigated in our sample. Moreover, functional expression of genes could be regulated differently in the two groups of children, for example, by epigenetic processes. Therefore, maternal genotype or environmental factors might affect the expression of the HTTLPR gene, representing another potential link between maternal genotype and the offspring's brain and behavior. However, our study precludes dissociating such mechanistic links. Given the sample size available, whole-gene or gene-group analyses were not yet possible in our group to test this possibility. Finally, our study is missing information on paternal characteristics, which can certainly also influence the developing child (Roggman et al., 2002).

Regardless of these limitations, this study provides initial evidence for the concept that normal variance in the maternal genotype has a substantial effect on the offspring that is independent of classical genetic inheritance. In other words, maternal genotype shapes differences between individuals who are genetically comparable. Therefore, future genetic studies should consider the maternal genotype and may also further investigate mechanistic links between maternal genotype and the child's phenotype.

\section{References}

Ashburner J, Friston KJ (2000) Voxel-based morphometry-the methods. Neuroimage 11:805-821. CrossRef Medline

Ashburner J, Friston KJ (2001) Why voxel-based morphometry should be used. Neuroimage 14:1238-1243. CrossRef Medline

Bakermans-Kranenburg MJ, van Ijzendoorn MH (2008) Oxytocin receptor (OXTR) and serotonin transporter (5-HTT) genes associated with observed parenting. Soc Cogn Affect Neurosci 3:128-134. CrossRef Medline

Bonnin A, Goeden N, Chen K, Wilson ML, King J, Shih JC, Blakely RD, Deneris ES, Levitt P (2011) A transient placental source of serotonin for the fetal forebrain. Nature 472:347-350. CrossRef Medline

Brett M, Anton J, Valabregue R, Poline J (2002) Region of interest analysis using an SPM toolbox. 8th Int Conferance Funct Mapp Hum Brain 16: (abstract 497).

Brooks BL, Sherman EM, Iverson GL (2010) Healthy children get low scores too: prevalence of low scores on the NEPSY-II in preschoolers, children, and adolescents. Arch Clin Neuropsychol 25:182-190. CrossRef Medline

Carlson BM (2008) Human embryonic developmental biology. Philadelphia: Mosby Elsevier.

Caspi A, Sugden K, Moffitt TE, Taylor A, Craig IW, Harrington H, McClay J, Mill J, Martin J, Braithwaite A, Poulton R (2003) Influence of life stress on depression: moderation by a polymorphism in the 5-HTT gene. Science 301:386-389. CrossRef Medline

Caspi A, Hariri AR, Holmes A, Uher R, Moffitt TE (2010) Genetic sensitivity to the environment: the case of the serotonin transporter gene and its implications for studying complex diseases and traits. Am J Psychiatry 167:509-527. CrossRef Medline

Chen CH, Gutierrez ED, Thompson W, Panizzon MS, Jernigan TL, Eyler LT, Fennema-Notestine C, Jak AJ, Neale MC, Franz CE, Lyons MJ, Grant MD, Fischl B, Seidman LJ, Tsuang MT, Kremen WS, Dale AM (2012) Hierarchical genetic organization of human cortical surface area. Science 335: 1634-1636. CrossRef Medline

Côté F, Fligny C, Bayard E, Launay JM, Gershon MD, Mallet J, Vodjdani G (2007) Maternal serotonin is crucial for murine embryonic development. Proc Natl Acad Sci U S A 104:329-334. CrossRef Medline

De Beurs E (2004) Brief Symptom Inventory, handleiding. Leiden, the Netherlands: PITS.

Derogatis L, Melisaratos N (1983) The Brief Symptom Inventory: an introductory report. Psychol Med 3:595-605. Medline

de Vries NK, van der Veere CN, Reijneveld SA, Bos AF (2013) Early neurological outcome of young infants exposed to selective serotonin reuptake 
inhibitors during pregnancy: results from the observational SMOK study. PLoS One 8:e64654. CrossRef Medline

El Marroun H, Jaddoe VW, Hudziak JJ, Roza SJ, Steegers EA, Hofman A, Verhulst FC, White TJ, Stricker BH, Tiemeier H (2012) Maternal use of selective serotonin reuptake inhibitors, fetal growth, and risk of adverse birth outcomes. Arch Gen Psychiatry 69:706-714. CrossRef Medline

El Marroun H, White TJ, van der Knaap NJ, Homberg JR, Fernández G, Schoemaker NK, Jaddoe VW V, Hofman A, Verhulst FC, Hudziak JJ, Stricker BH, Tiemeier H (2014) Prenatal exposure to selective serotonin reuptake inhibitors and autistic symptoms in young children. Br J Psychiatry, in press.

Eyler LT, Prom-Wormley E, Panizzon MS, Kaup AR, Fennema-Notestine C, Neale MC, Jernigan TL, Fischl B, Franz CE, Lyons MJ, Grant M, Stevens A, Pacheco J, Perry ME, Schmitt JE, Seidman LJ, Thermenos HW, Tsuang MT, Chen CH, Thompson WK, et al. (2011) Genetic and environmental contributions to regional cortical surface area in humans: a magnetic resonance imaging twin study. Cereb Cortex 21:2313-2321. CrossRef Medline

Gaspar P, Cases O, Maroteaux L (2003) The developmental role of serotonin: news from mouse molecular genetics. Nat Rev Neurosci 4:10021012. CrossRef Medline

Halmøy A, Johansson S, Winge I, McKinney JA, Knappskog PM, Haavik J (2010) Attention-deficit/hyperactivity disorder symptoms in offspring of mothers with impaired serotonin production. Arch Gen Psychiatry 67:1033-1043. CrossRef Medline

Heils A, Teufel A, Petri S, Stöber G, Riederer P, Bengel D, Lesch KP (1996) Allelic variation of human serotonin transporter gene expression. J Neurochem 66:2621-2624. CrossRef Medline

Hendrick V, Stowe ZN, Altshuler LL, Hwang S, Lee E, Haynes D (2003) Placental passage of antidepressant medications. Am J Psychiatry 160: 993-996. CrossRef Medline

Herholz SC, Zatorre RJ (2012) Musical training as a framework for brain plasticity: behavior, function, and structure. Neuron 76:486-502. CrossRef Medline

Homberg JR, Lesch KP (2011) Looking on the bright side of serotonin transporter gene variation. Biol Psychiatry 69:513-519. CrossRef Medline

IJzendoorn MH, Bakermans-Kranenburg MJ (2004) Conflict oplossen in de opvoeding van jonge kinderen. Unversiteit Leiden: Cent voor Gezinsstudies.

Jaddoe VW, van Duijn CM, van der Heijden AJ, Mackenbach JP, Moll HA, Steegers EA, Tiemeier H, Uitterlinden AG, Verhulst FC, Hofman A (2010) The Generation R Study: design and cohort update 2010. Eur J Epidemiol 25:823-841. CrossRef Medline

James SJ, Melnyk S, Jernigan S, Pavliv O, Trusty T, Lehman S, Seidel L, Gaylor DW, Cleves MA (2010) A functional polymorphism in the reduced folate carrier gene and DNA hypomethylation in mothers of children with autism. Am J Med Genet 153B:1209-1220. CrossRef Medline

John R, Hemberger M (2012) A placenta for life. Reprod Biomed Online 25:5-11. CrossRef Medline

Korkman M, Lahti-Nuuttila P, Laasonen M, Kemp SL, Holdnack J (2013) Neurocognitive development in 5- to 16-year-old North American children: a cross-sectional study. Child Neuropsychol 19:516-539. CrossRef Medline

Lahey BB, Michalska KJ, Liu C, Chen Q, Hipwell AE, Chronis-Tuscano A, Waldman ID, Decety J (2012) Preliminary genetic imaging study of the association between estrogen receptor- $\alpha$ gene polymorphisms and harsh human maternal parenting. Neurosci Lett 525:17-22. CrossRef Medline

Lee LJ (2009) Neonatal fluoxetine exposure affects the neuronal structure in the somatosensory cortex and somatosensory-related behaviors in adolescent rats. Neurotox Res 15:212-223. CrossRef Medline

Lesch KP, Bengel D, Heils A, Sabol SZ, Greenberg BD, Petri S, Benjamin J, Müller CR, Hamer DH, Murphy DL (1996) Association of anxiety- related traits with a polymorphism in the serotonin transporter gene regulatory region. Science 274:1527-1531. CrossRef Medline

Maguire EA, Gadian DG, Johnsrude IS, Good CD, Ashburner J, Frackowiak RS, Frith CD (2000) Navigation-related structural change in the hippocampi of taxi drivers. Proc Natl Acad Sci U S A 97:4398-4403. CrossRef Medline

Miceli S, Negwer M, van Eijs F, Kalkhoven C, van Lierop I, Homberg J, Schubert D (2013) High serotonin levels during brain development alter the structural input-output connectivity of neural networks in the rat somatosensory layer IV. Front Cell Neurosci 7:88-103. CrossRef Medline

Nicol-Harper R, Harvey AG, Stein A (2007) Interactions between mothers and infants: impact of maternal anxiety. Infant Behav Dev 30:161-167. CrossRef Medline

Olivier JDA, Vallès A, van Heesch F, Afrasiab-Middelman A, Roelofs JJPM, Jonkers M, Peeters EJ, Korte-Bouws GAH, Dederen JP, Kiliaan AJ, Martens GJ, Schubert D, Homberg JR (2011) Fluoxetine administration to pregnant rats increases anxiety-related behavior in the offspring. Psychopharmacology (Berl) 217:419-432. CrossRef Medline

Pedersen LH, Henriksen TB, Olsen J (2010) Fetal exposure to antidepressants and normal milestone development at 6 and 19 months of age. Pediatrics 125:e600-8. CrossRef Medline

Pilsner JR1, Hu H, Wright RO, Kordas K, Ettinger AS, Sánchez BN, Cantonwine D, Lazarus AL, Cantoral A, Schnaas L, Téllez-Rojo MM, HernándezAvila M (2010) Maternal MTHFR genotype and haplotype predict deficits in early cognitive development in a lead-exposed birth cohort in Mexico City. Am J Clin Nutr 92:226-234. CrossRef Medline

Rodriguez-Porcel F, Green D, Khatri N, Harris SS, May WL, Lin RCS, Paul IA (2011) Neonatal exposure of rats to antidepressants affects behavioral reactions to novelty and social interactions in a manner analogous to autistic spectrum disorders. Anat Rec 294:1726-1735. CrossRef Medline

Roggman LA, Boyce LK, Cook GA, Cook J (2002) Getting dads involved: predictors of father involvement in Early Head Start and with their children. Infant Mental Health Journal 23:62-78. CrossRef

Roza SJ, Verburg BO, Jaddoe VW, Hofman A, Mackenbach JP, Steegers EA, Witteman JC, Verhulst FC, Tiemeier H (2007) Effects of maternal smoking in pregnancy on prenatal brain development: the Generation $\mathrm{R}$ Study. Eur J Neurosci 25:611-617. CrossRef Medline

Straus MA, Hamby SL, Finkelhor D, Moore DW, Runyan D (1998) Identification of child maltreatment with the Parent-Child Conflict Tactics Scales: development and psychometric data for a national sample of American parents. Child Abuse Negl 22:249-270. CrossRef Medline

Tiemeier H, Velders FP, Szekely E, Roza SJ, Dieleman G, Jaddoe VW, Uitterlinden AG, White TJ, Bakermans-Kranenburg MJ, Hofman A, Van Ijzendoorn MH, Hudziak JJ, Verhulst FC (2012) The Generation R Study: A review of design, findings to date, and a study of the 5-HTTLPR by environmental interaction from fetal life onward. J Am Acad Child Adolesc Psychiatry 51:1119-1135.e7. CrossRef Medline

Wallingford JB, Niswander LA, Shaw GM, Finnell RH (2013) The continuing challenge of understanding, preventing, and treating neural tube defects. Science 339:1222002. CrossRef Medline

Weikum WM, Oberlander TF, Hensch TK, Werker JF (2012) Prenatal exposure to antidepressants and depressed maternal mood alter trajectory of infant speech perception. Proc Natl Acad Sci U S A 109:17221-17227. CrossRef Medline

White T, El Marroun H, Nijs I, Schmidt M, van der Lugt A, Wielopolki PA, Jaddoe VW, Hofman A, Krestin GP, Tiemeier H, Verhulst FC (2013) Pediatric population-based neuroimaging and the Generation R Study: the intersection of developmental neuroscience and epidemiology. Eur J Epidemiol 28:99-111. CrossRef Medline

Wilke M, Schmithorst VJ, Holland SK (2003) Normative pediatric brain data for spatial normalization and segmentation differs from standard adult data. Magn Reson Med 50:749-757. CrossRef Medline 